\title{
СОВРЕМЕННЫЙ ИСЛАМИЗМ КАК ПОЛИТИЧЕСКИЙ СПОСОБ РЕАЛИЗАЦИИ ИСЛАМСКОГО ЦИВИЛИЗАЦИОННОГО ПРОЕКТА (АФРИКАНСКИЙ ОПЫТ)
}

\section{MODERN ISLAMISM AS A POLITICAL WAY TO IMPLEMENT AN ISLAMIC CIVILIZATION PROJECT (AFRICAN EXPERIENCE)}

\section{R. Bobokhonov}

Summary: Islamism is active today not only in Europe and Asia, but also in Africa. Radical and Islamist currents of Islam under the leadership of Al Qaeda are gradually moving south of the Sahara and deep into Tropical Africa. «Boko Haram», «Ash-Shabab», «Ansar ad-Din», «Seleka» and other organizations are prime examples. The ideology of these organizations is Salafi and is based on a worldwide jihad for the creation of the World Caliphate. The creation of an Islamic state in one country and further unite with other Islamic states within the framework of the World Caliphate is an Islamic civilization project. Modern Islamism is trying to implement this project all over the world, including in Africa.

Keywords: modern Islamism, Islamic civilization project, radical Islam, Islamic state, World Caliphate, Salafism, Sufism.

\author{
Бобохонов Рахимбек Сархадбекович \\ С.н.С., Центр чивилизачионных и региональных \\ исследований Института Африки РАН \\ rahimbobokhonov@yandex.ru
}

Аннотация: Исламизм сегодня активен не только в Европе и Азии, но и в Африке. Радикальные и исламистские течения ислама под руководством «Аль Каиды» постепенно перемещаются южнее Сахары и вглубь Тропической Африки. «Боко харам», «Аш-шабаб», «Ансар ад-Дин», «Селека» и другие организации являются яркими примерами. Идеология этих организации салафитская и основана на всемирный джихад ради создание Всемирного Халифата. Создание Исламского государства в одной стране и далее объединиться с другими исламскими государствами в рамках Всемирного Халифата - это и есть исламский цивилизационный проект. Современный исламизм пытается реализовать этот проект во всем мире, в том числе в Африке.

Ключевые слова: современный исламизм, исламский цивилизационный проект, радикальный ислам, исламское государство, Всемирный Халифат, салафизм, суфизм.

Теперь немного об источниках и свойствах исламизма. Об этом рассуждают многие зарубежные исламоведы. Например, профессор Дамаскского университета Садик аль-Азм считает, что исламизм - это крайне воинственная и мобилизующая идеология, развитая на основе избранных священных писаний, текстов, легенд Ислама, исторических прецедентов, организационного опыта и современных обид и печалей. Всё это представляет собой защитную реакцию против долговременной эрозии главенствующей роли Ислама в общественной, институциональной, экономической, социальной и культурной жизни мусульманских обществ в 20-ом столетии. Эта идеология вводится в практику через возрождение давнишнего понятия исламского джихада (священной войны) в его самых сильных и агрессивных формах, войны против окружающего мира язычества, многобожия, идолопоклонства, безбожия, атеизма, предательства и неверия, известного этой идеологии как вероотступничество (Jahiliyyah) 20-ого столетия. (Jahili, джахили, - сознательное, умышленное игнорирование норм ислама автор)[2].

Окончательная цель исламизма состоит в спасении современного мира от этого состояния - Jahili, навязанного ему современным Западом. Это должно произойти таким же способом, каким возвышение и быстрое 
распространение Ислама 1300 лет назад спасло мир от очень похожего состояния Jahili, доминировавшего над миром тогда[2].

Результаты претворения в жизнь этого великого спасительного проекта в настоящее время вполне очевидны и проявляются:

- в процессах реисламизации, которые происходят уже сейчас в лишь «номинально» мусульманских странах и обществах;

- во внутреннем вооруженном джихаде против отступнических режимов, доминирующих сейчас во всех так называемых мусульманских государствах и правящих всеми так называемыми мусульманскими областями;

- во внешнем великом джихаде против глобального нечестивого союза Западных современных крестоносцев с миром Еврейства и Сионизма[2].

Далее Садик аль-Азм рассуждает об идеологии и практики исламизма:

- это фундаментализм, потому, что он представляет себя подлинным движением возвращения к теперь уже забытым «основным принципам» (usul) и «основам» (usus) Ислама и их восстановления, со специальным акцентом на забытом было императиве и обязательности самого Джихада;

- это возрождение, потому, что он представляет себя основным элементом двойного процесса: восстановления таких основных принципов, как активная вера и действенные обряды в жизни мусульман, и возрождения бездействующих в настоящее время масс мусульманского мира путем введения их в жизнь, сердца, умы и государственные структуры забытых основных мусульманских принципов;

- это интегрализм, потому что его непосредственная цель состоит в объединении всех автономных аспектов, областей и сфер современного общества и жизни, включая социальный, экономический, политический, культурный, научный, эстетический, внутренний, персональный, религиозный, духовный и т.д. - под властью религии Аллаха и правления в соответствии с его законами Шариата;

- это теократизм, потому что его объявленная программа имеет своей целью восстановить Аллаха как Haimiyyah, т.е. Верховную власть или Владычество, над всеми его бунтующими человеческими существами в современный период вообще и 21-ом столетии, в особенности через создание истинно мусульманских государств и государственных аппаратов;

- это теономизм (в буквальном переводе «главенство законов Господа» - автор), потому что его непосредственная цель - прямое, буквальное и всестороннее выполнение и применение закона Шариата, данного Аллахом. Этот закон является абсолютным, цельным и не могущим быть объектом каких-либо человеческих обсуждений;

- это терроризм, из-за провозглашенной им открыто потери надежды на возможность использования какого-либо иного метода или средств достижения целей и программ исламизма, кроме немедленной и прямой атаки на внутреннего и внешнего врага так жестоко, неожиданно, сильно, эффективно и уничтожительно, как только это возможно. При этом не должны учитываться долговременные последствия успеха или неудачи такой борьбы. Напротив, следует презирать их, разрушительные последствия, и пренебрегать их социальными, политическими и экономическими последствиями даже для самого исламизма. И все это потому, что для исламизма наиболее важно поразить врагов там, где это для них наиболее болезненно. А ничто не может быть более болезненным, чем взрыв их невинных граждан и просто случайных прохожих [2].

Известный американский исламовед Даниэль Пайпс считает, что исламизм - это третья тоталитарная идеология (после фашизма и коммунизма) и предлагает нелепый средневековый подход к проблемам современной жизни. Ретроградный и агрессивный, он притесняет не мусульман, угнетает женщин и оправдывает распространение власти ислама с помощью силы. Более того, что исламизм - это реакция клерикальных кругов на научное и материальное отставание исламского мира в XX столетии, на модернизационные процессы современного мира и т. д. [3].

В ходе и после событий «арабской весны», как было отмечено выше, возросла роль исламистского движении не только в Северной, но и в Тропической Африке. Помимо активного участия в радикальных течениях ислама, таких как «Боко харам», «Аш - Шабаб», «Ансар ад-дин», «Селека» и другие, многие исламисты включились в мировой сетевой ислам. Самыми активными и посещаемыми исламскими сайтами стали исламистские. В отличие от «Братьев - мусульман», которые непосредственно включились в политическую борьбу в реальной жизни в Египте и Тунисе, исламисты начали свою борьбу в социальных сайтах Интернета. Более того, исламисты раньше всех подключились к мировому сетевому исламу, поскольку агитацию и пропаганду «чистого ислама» они вели на протяжении всего XX века. Появление Интернета и социальных сайтов открыло исламиста новые важные трибуны для продвижения своих идей в мировом информационном пространстве.

В отличие от старшего поколения идейных ислами- 
стов - салафитов, которые мирно распространяли свои идеи в мечетях, в религиозных школах, медресе и университетах, молодые салафиты в социальных сайтах объединялись не только идейно, но и политически, занимая враждебную позицию по отношению к другим религиозным партиям и организациям во всем мусульманском мире. Таким образом, в онлайн-пространстве постепенно формировалось джихадистское направление салафизма, его сторонник выходило на улицу, чтобы реализовать свои идеи вооруженным путем. Для реализации своих идей салафиты - джихадисты выбрали две страны -Тунис и Египет; правда, в этом им помешали «Братья - мусульмане», которые пришли к власти и хотели постепенно отмежеваться от всего салафитского движения в ближайшей перспективе [4]. Но исламистысалафиты в Тропической Африке начали реализовывать свои идеи в ходе вооруженной борьбы в составе радикальных и исламистских организации - в Нигерии(«Боко харам»)[5], Сомали, Кении, Танзании(«Аш-шабаб»)[6], в Мали(«Ансар ад-дин»)[7], в Центрально-Африканской Республике («Селека»)[8] и т.д. Основную борьбу в странах Тропической Африки салафиты развернули против светских государств, против христианского населения, суфийского ислама и его исторического наследия (святых и культовых сооружений, мазаров, медресе, библиотек с архивными рукописями и т.д.).

Цивилизационная модель исламизма и салафизма в Тропической Африке. Основные черты исламизма и салафизма в Тропической Африке таковы: создание отделенных от других мусульман общин; отказ от традиционных форм почитания старших и уважения марабутов; отказ от культа святых; обращение исключительно к Корану и Сунне Пророка в качестве источников веры; демонстративно выражаемое недоверие к любым (за исключением исламской) правовым системам; враждебное отношение к тарикатам, которые расцениваются «пуританами ислама» как новаторские и еретические секты, искажающие смысл и содержание веры. Все мировые религии, включая классический ислам, призывают к самосовершенствованию, к «работе над собой». Приверженцы салафизма априори «безгрешны», их основная задача - «исправить других». Там, где получают распространение подобные формы ислама, возникают свои собственные органы самоуправления, там имущественные, семейные и уголовные проблемы решаются лидером местной мусульманской общины на основе норм шариата. Представители действующей светской власти встречаются с населением только на свадьбах и похоронах. Салафитские проповедники всегда среди простых людей [7].

Религиозное учение африканских исламистов-салафитов делит мир на «дар уль ислам» - «мир ислама», территорию, где действует религиозный закон и где полити- чески господствуют мусульмане, и «дар уль харб» - «мир войны», территорию, где исламский закон не действует, где мусульмане подвергаются притеснениям и ислам еще не утвердился. Главная задача мусульманской уммы, с точки зрения салафитов, - стремиться к тому, чтобы «дар уль харб» превратился в «дар уль ислам». Пути к этой цели могут быть разными - военные завоевания, проповеди истинной религии - ислама и добровольное обращение населения в эту религию.

Другим важнейшим принципом исламистской и салафитской доктрины в Тропической Африке является джихад, который трактуется как усердие, старание, любая форма деятельности мусульман (индивидуальная или коллективная), направленная на следование человека по пути Аллаха. Он обязателен абсолютно для всех мусульман. Джихад разделяется на большой и малый. Большой джихад - борьба со своими собственными отклонениями от пути Аллаха. Малый - «джихад меча», он может проявляться в двух формах. Наступательный джихад - распространение ислама на «дар уль харб». Оборонительный джихад объявляется при угрозе исламу или нападении на «дар уль ислам». Принцип джихада отвергает все законы старого мира неверных и призывает к революционной борьбе за торжество ислама. При этом джихад трактуется как применение насилия в разных формах для достижения религиозного идеала [9].

Такова цивилизационная модель общественного устройства, которую салафиты предлагают в Тропической Африке. Основная политическая цель при этом путем джихада - вооруженной борьбы построить исламское государство в странах этого региона. Главный враг в регионе не христиане, а представители суфизма, которые исповедуют, по мнению слафитов, неверный и не подлинный ислам. Традиционные мусульманские объединения - духовные ордены (тарикаты) мирно сосуществуют с христианами и местными правителями, не хотят бороться за исламское государство. Поэтому салафиты для реализации своего глобального проекта - создания Всемирного халифата выдвигают главную задачу - вытеснить и уничтожить суфийский ислам в регионе. В политических установках и программах салафитских группировок отличаются тем, что в их учении, которое они расценивают как единственно правильную трактовку ислама, присутствуют два непременных системообразующих, присущих салафизму положения: о такфире (обвинение в неверии - куфр - всех мусульман, кто не согласен с салафитами) и о джихаде, который преподносится как вооруженная борьба, вменяемая в обязанность каждому мусульманину, против неверных (кяфиров). Необходимо при этом иметь в виду, что данные термины - не просто оценочные характеристики, а шариатско-правовые категории. Их использование по отношению к тому или иному мусульманину или группе 
мусульман предполагает обязательность применения конкретных санкций. Под эти санкции, конечно, попадают представители традиционного ислама - суфизма.

Как мы видим, цивилизационные вызовы исламизма и салафизма в Тропической Африке направлены не только против местных христиан, существующих там государств и правителей, но и против мусульман, которые являются последователями различных суфийских тарикатов.

«Боко харам» против суфизма. Нигерийские исламисты из группировки «Боко харам» исходят из положения об абсолютной власти Аллаха над всем сущим на Земле и над людьми. Власть в обществе должна принадлежать религиозным деятелям, разделяющим идеи «истинной веры», т.е. халифу Исламского государства и его приближенным. Настоящие лидеры не назначаются, и не избираются, даже внутри уммы, а выделяются самим Аллахом. Власть исходит из ниспосланной свыше некой божественной сверхидеи, которая существует независимо от людей и помимо их воли. Истинным верующим является тот, кто правильно ее понимает, т. е., говоря современным языком, обладает монополией на истину. Все остальные, включая подавляющее большинство мусульман, являются «язычниками», так как им не хватает истинной религиозности. Они лишь внешне копируют обряды поклонения Аллаху, но не понимают природу божественности. Именно поэтому в настоящее время человечество вернулось в период доисламского невежества (джахилийя), которое опаснее и греховнее предыдущего. Подлинное предназначение «Боко харам» - помочь «заблуждающимся» и «язычникам» обрести истинную веру. Для этого приемлемы любые пути, а цель оправдывает средства ее достижения [5].

«Ансар ад-Дин» разрушает каноны суфизма. Члены исламистской группировки «Ансар ад-Дин» («Защитники веры» в переводе с арабского), удерживающие под своим контролем обширную территорию на севере Мали, разрушили в древнем городе Томбукту памятники архитектуры, культуры и истории ислама, внесенные В список Всемирного наследия ЮНЕСКО. В этот перечень были включены, в частности, три мечети, главное медресе Томбукту и 16 из 333 захоронений шейхов, которых почитают как аулия (приближенные к Аллаху. Р.Б.). Одно из захоронений - Сиди Махмуда (Бен Амара) - существовало с 1548 года. Следует отметить, что разрушение гробниц - не первый акт вандализма со стороны «ансаров» в Мали. Весной 2012 года они подожгли одну из мечетей и разграбили основанный в 1973 году Центр сбора архивных документов и исследований имени Ахмеда Бабы. По данным министерства культуры Мали, в библиотеке Центра хранилось от 60 до 100 тысяч средневековых рукописных свитков, содержавших бесценную информацию о развитии и истории ислама в Запад- ной Африке. Вообще в Томбукту хранится около 300000 манускриптов мусульманской цивилизации в Африке. Город, который был основан еще в XI веке, благодаря таким «защитникам» ислама, оказался под угрозой полной утраты своего великого исторического наследия [7].

«Аш - Шабаб» и джихад в Африканском Роге. В Сомали между 2004 и 2006 годами образовалась исламистская вооруженная группировка «Аш-Шабаб». На тот момент страна уже около 15 лет находилась в состоянии тяжелой гражданской войны. Название организации означает «молодость» в переводе с арабского. «Аш-Шабаб» борется за создание исламского государства в районе Африканского Рога. Ее радикально-джихадистская идеология не знает государственных границ. В настоящее время группировка совершает нападения на территории всей Восточной Африки, например, в столице Кении Найроби, здесь во время налета на торговый центр в 2013 году было убито более 60 человек. «Аш-Шабаб» контролирует территорию в центре и на юге Сомали. Лидеры организации подчеркивают, что сотрудничают с «Аль-Каидой» при подготовке боевиков. Кроме того, группировка имеет связи с радикальными исламистами из группировки «Боко Харам» [6].

Политизации «Селеки» В ЦАР. Религиозный конфликт в Центрально-Африканской Республике представляет собой довольно сложную структуру: с одной стороны находится правительственная власть ЦАР, с другой - повстанческие группировки, представляющие христианскую и мусульманскую общины страны. Салафитский альянс повстанцев «Селека» включает в себя несколько террористических группировок, ныне базирующихся на северо-востоке страны. В принципе, именно «Селека» В 2013 году произвела государственный переворот, захватив сначала несколько городов, а затем и президентский дворец в городе Банги. После переворота глава «Селеки» Мишель Джотодия провозгласил себя президентом страны. Власть практически была захвачена только в Банги, а на остальной территории страны, по свидетельству наблюдателей ООН, «государства фактически не было». Иными словами, за пределами столицы не было никакой безопасности и законности: не было ни полицейских, ни прокуроров, ни судей. В стране стали орудовать бойцы «Селеки», которые занимались грабежам и вымогательством, причем только в отношении христианского населения. Затем салафиты «Селека» начали выступать против суфизма во всех его проявлениях [8].

Как мы видим, джихадистский салафизм как форма исламизма не только борется за чистоту ислама, но и активно занимается политикой. Процесс политизации ислама в странах Тропической Африки набирает обороты. Если раньше тарикаты на прямую не занимались политикой, то нынешние салафиты не только стали ее заниматься, но переходить к ее крайней форме-сверже- 
ние государственной власти в странах региона, чтобы построит исламское государство. Такая жесткая политическая позиция салафитов ставит в уголь тарикатов и его последователей. Поэтому многие представители тарикатов вынуждены присоединится к салафитам. Таким образом, мирный и суфийский ислам постепенно утрачивает свои позиции в странах региона и уходит в прошлое.

Исламизм приходит в Тропическую Африку под знаменами джихадистского салафизма. Страны Тропической Африки, конечно, не готовы к приходу исламизма и салафитского джихада. Не готовы христиане и тарикаты. Светские африканские режимы раньше опирались на поддержку тарикатов и их шейхов, которые имели огромные авторитеты среди местного мусульманского населения. Теперь эти шейхи бояться салафитов и не могут поддерживать руководителей этих стран. Диалог и спор между салафитами и тарикатами по многим политическим, экономическим и религиозным вопросам, как правило, заканчивается в пользу салафитов. Между существующих режимов и салафитов никакого мирного диалога не происходит, идет война «Аль Каиды», «Боко харама», «Аш -Шабаба», «Селеки», «Ансар ад -дина» и т.д. против местных властей на протяжении многих лет. Процессы радикализации ислама и вытеснение мирного суфийского ислама в регионе исключают какого угодно диалога между воюющих сторон и наступление мира. Прогнозы не утешительны, поскольку джихадистское направление салафизма явление относительно новое и оно, возможно, еще много лет будет вызревать, пока не наступит кризис и не уходит из политической и религиозной жизни общества.

Тем не менее, в последние годы реакция международного сообщества на происходящих событий в странах Тропической Африки в связи с ростом исламизма и салафизма, стала более заметна. Создаются разные программы по дерадикализации исламистских группировок в странах региона. Опыт по дерадикализии «Боко харама» оказался неудачным. Военные рейды со стороны разных стран против пиратов «Аш - Шабаба» в Сомали проводятся регулярно, иногда с успехом. Страны региона часто создают объединенные вооруженные силы против исламистов в Сомали, Нигерии, Мали, Камеруне и Чаде, но истребить и уничтожит боевиков салафитского джихада им не по силу. Исламизм, терроризм и бандитизм в некоторых мусульманских Тропической Африки, по-прежнему, продолжается.

Наш анализ показывает, что в последние годы джихадистский салафизм как форма исламизма все больше распространяется в Тропической Африке. У джихадисткого салафизма четко определены цели и задачи. «Аль Каида» и его подразделения хорошо финансируют салафитов по всей Африке. Для достижения главной цели - создание исламского государства нужны не только финансовые, но и людские ресурсы. Поэтому салафитские группировки пытаются объединиться, чтобы иметь более сплоченную структуру для захвата власти в странах региона. В последние годы часто к салафитам присоединяются молодые ученики суфийских тарикатов, таким образом, они пытаются уходить от жесткого преследования воинствующих салафитов. Здесь мы видим рустующую роль салафизма в религиозных интеграционных процессах в мусульманских обществах региона. Следует отметить, что этот интеграционный процесс имеет принудительный и насильственный характер, но его темпы довольно ощутимы в странах Тропической Африки. Эти интеграционные процессы имеют двоякую цель: с одной стороны, объединиться под знаменем джихада для создания исламского государства, с другой стороны, бороться против христиан и тарикатов, которые, по мнению салафитов, не являются настоящими мусульманскими течениями в исламе. Таким образом, салафизм в последние годы не только контролирует, но и руководит религиозными интеграционными процессами в мусульманских обществах Тропической Африки.

Перспективы исламизма и исламистского проекта в Тропической Африке. Создается ощущение, что исламизм и движение салафитского ислама утвердились в Тропической Африке всерьез и надолго. Это начинают понимать даже руководители тех стран Африки, где еще не так давно вообще не было мусульман. Например, руководители Анголы, в соответствии с действующим законодательством страны, в 2015 г. запретили ислам и снесли все мечети [13]. Даже если будут ликвидированы салафитские группировки «Боко харам», «Аш-Шабаб», «Ансар ад-дин», «Селека» и другие, то им на смену в любом африканском мусульманском обществе обязательно придут аналогичные организации. Идеологию невозможно победить с помощью оружия. Она может утратить свое влияние на массы только в том случае, если они воспримут иное учение.

В заключение следует отметить, что в последние годы ислам стал составной частью социально-экономической и политической жизни многих стран Африки, и рост его влияния может существенно изменить цивилизационный облик многих из них. Мусульманские социально-политические институты не только воздействуют на соответствующие государственные структуры, но и выступают иногда как наиболее действенная им альтернатива. Все активнее становятся силы, ратующие за построение общества, основанного на исламских законах и духовных ценностях. Рустующие вызовы исламизма могут изменить баланс социально-экономических, политических, религиозных сил и усилить цивилизационный кризис в Тропической Африке. 


\section{ЛИТЕРАТУРА}

1. Игнатенко А.А. От Филиппин до Косово // Независимая газета, 12.10.2000.

2. Садик Дж. аль-Азм. Что такое Исламизм?// Newsletter. №3.15.02.2006.

3. Даниэль Пайпс. Без друзей на Ближнем Востоке // National Review Online, 08. 11. 2011.

4. Бобохонов Р.С. Возникновение ИГИЛ - как результат активной политизации ислама // www. centrasia. ru / newsA.php?st=1419067980.

5. Бобохонов Р.С. Радикальные течения ислама в мире: «Боко харам» Центральная Азия. 5. 9. 2017. Постоянный электронный адрес статьи: http: // www. centrasia. ru / news. php? St $=1504600680$.

6. Бобхонов Р.С. Радикальные течения ислама в мире - Аш-Шабаб// Современная наука: актуальные проблемы теории и практики. Серия «Гуманитарные науки». -№8. -2018, -с.8-13.

7. Бобохонов Р.С. Радикальные течения ислама в Африке: Ансар ад-дин. Мали// Современная наука: актуальные проблемы теории и практики. Серия «Гуманитарные науки». -№6/2. -2020, -с.6-10.

8. Бобохонов Р.С. Радикальные течения ислама в Африке: «Селека»// Современная наука: актуальные проблемы теории и практики. Серия «Гуманитарные науки». -№8. -2019. -С.6-16.

9. Бобохонов Р.С. Участие радикальных исламистских движений в современных африканских конфликтах: религиозная и нерелигиозная составляющие (на примере организации «Боко Харам») // Сборник материалов «Религиозные конфликты в Африке южнее Сахары: угрозы нарастания и возможности предотвращения». Москва: Институт Африки РАН, 2019 С. 41-46.

10. Запрет ислама в Анголе может иметь глобальные последствия//Рамблер. 08.09.2015.

\footnotetext{
(с) Бобохонов Рахимбек Сархадбекович (rahimbobokhonov@yandex.ru).

Журнал «Современная наука: актуальные проблемы теории и практики»
}

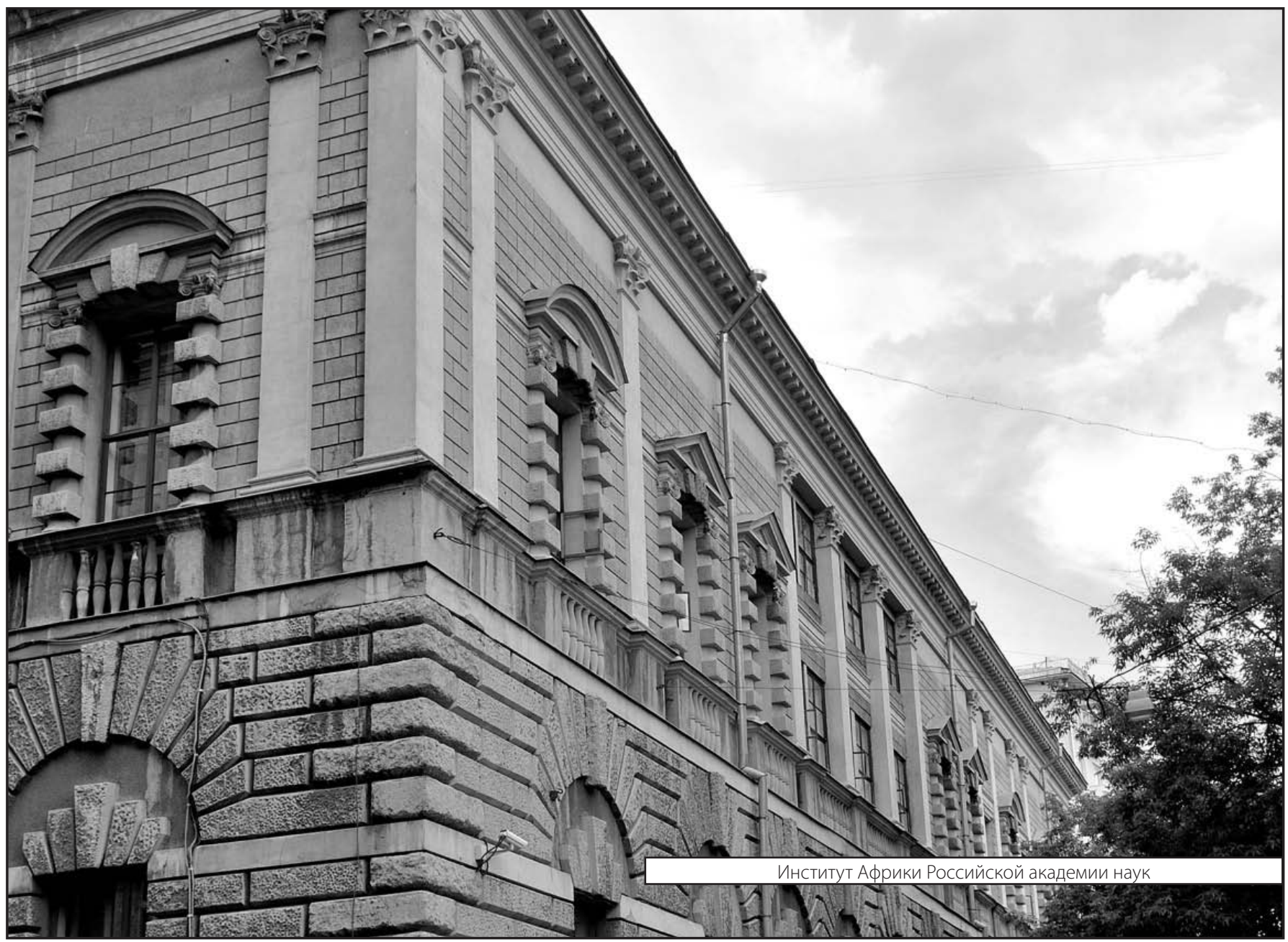

